\title{
European Paper-Covered Books from the Fifteenth through the Eighteenth Centuries
}

\author{
M I C H E L E V. C L O O N A N
}

Paper book coverings ${ }^{1}$ occupy a distinctively ambiguous position in the history of bookbinding. Their often hybrid styles range from simple wrappers and laced-in constructions to the early cased bindings of the eighteenth century. Their conditions of manufacture are no less diffuse: they were produced not only by bookbinders, but by printers, booksellers, librarians, and private collectors as well. For such reasons they defy classification as either fine or trade bindings.

A book's cover may not reflect its contents, but it may reflect the taste of its owner, as well as the use-or non-use-of the book. For example, books were sometimes given deluxe bindings but then relegated to private library shelves unread. These elegant volumes may have enhanced the interior decoration of the room rather than informed the mind of the owner.

Other books, plainly bound or simply wrappered, may have been used extensively. The owners of these volumes may have been more interested in their contents. Or perhaps they could not afford fancy bindings. But there were other reasons papercovered books were selected.

Collectors such as Madame de Pompadour (1721-64)-a prodigious reader ${ }^{2}$ - wanted her books "hot off the press." A simple paper wrapper could be attached quickly, and the book

${ }^{1}$ The term covers is used here to designate bindings in boards as well as limp- and rigid-case bindings, but not wrappers; the term coverings applies to both bindings and wrappers.

${ }^{2}$ Nancy Mitford, Madame de Pompadour. rev. ed. London: Hamish Hamilton, 1968, 181 and 183, and Ernest Quentin Bouchart, "Madame de Pompadour" in his Les femmes bibliophiles de France, XVI, XVII et XVIII siecles, 2 vols.; vol. 2, 57, 64-65. Paris: Damascène Margand, 1886. 
more fully bound in leather after it had been read. In practice, Madame de Pompadour did not always bother to have her books bound, but the ones that she did were elegantly covered in calf or in red-, blue-, or lemon-colored morocco, gilt with her coat of arms. A close reading of the catalog of her library (which contained over 3,700 titles) reveals that many of her books were left in their (probably original) wrappers. ${ }^{3}$

Samuel Pepys (1633-1703), an earlier collector whose library was of comparable size to Pompadour's, also had papercovered books. But Pepys's upbringing, more puritanical than Madame de Pompadour's, dictated his taste. He liked order, uniformity, and respectability. ${ }^{4} \mathrm{He}$ was careful about how much he spent for bindings, and the majority of his books were covered in brown calf with restrained gold tooling. ${ }^{5}$ Sometimes he apparently also sought an eye-catching yet inexpensive alternative to his "brown books," and about 75 of his volumes are covered in marbled, Dutch gilt, or paste papers. Specially designed labels embellished the covers of these books, giving them the status of permanency usually reserved for leatherbound books and implying that Pepys recognized that status.

Madame de Pompadour and Samuel Pepys each recognized different advantages of paper-covered books: Pompadour their utilitarian uses (she could obtain her books quickly), and Pepys their monetary and aesthetic advantages (cheap yet attractive).

Examples of both deluxe and paper covers are prevalent in the history of bookbinding, though scholarly attention has tended to focus on what has come to be known as fine binding (read leather). Yet paper covers have an established tradition of their own that deserves examination so that the functions of paper-covered books can be better understood.

\footnotetext{
${ }^{3}$ Catalogue des livres de la bibliotheque de feue Madame La Marquise de Pompadour, Dame du Palais de la Reine. Paris: Jean-Th. Herissant, 1765. My figure includes the 3,525 titles in the main section of the catalog as well as the 235 titles of music which are classed separately. Of these titles, 241 are described as broché, and one each as blanc, cart., and br. en cart. The term broché means paper wrappered.

${ }^{4}$ Pepys Library, Magdalene College, Cambridge. The Pepys Library. Cambridge: University Printing Services, n.d., 14, and Arthur Bryant, Samuel Pepys: The Man in the Making. London: Granada, 1967, 5-6.

${ }^{5}$ Conversations with Richard Luckett, Pepys Librarian, March 10-12, 1987.
} 
In the past, studies have focused on specific types of paper book covers. For example, Giles Barber, William A. Jackson, and the elder Paul Kristeller ${ }^{6}$ have written about printed wrappers and publishers' bindings; Sophie Malavieille and Ruari McLean ${ }^{7}$ on nineteenth-century publishers' bindings. Others, such as Mirjam M. Foot and Howard M. Nixon, ${ }^{8}$ have briefly described some pre-nineteenth century paper book covers. Another approach has been through genre. F. J. Harvey Darton, Jacques Paul Dauriac, Sydney Roscoe, and Roy McKeen Wiles ${ }^{9}$ have written on children's books, almanacs, and serial publications-all of which include paper-covered exemplars. Still missing is an integrated approach to the subject that examines these books in the aggregate. Such an approach would identify the types of covers produced, their conditions of manufacture (whether by printer, binder, bookseller, librarian, or collector), and their role in the book trade.

The history of paper book covers begins with the fifteenth century, although paper was available in Western Europe as early as the late twelfth century. The earliest known specimen, dated 1482,10 is a paper woodcut wrapper from Augsburg,

${ }^{6}$ Giles Barber, "Continental Paper Wrappers and Publishers' Bindings in the 18th Century." Book Collector 24 (Spring 1975): 37-49; William A. Jackson, "Printed Wrappers of the Fifteenth to the Eighteenth Centuries." Harvard Library Bulletin 6 (Autumn 1952): 313-21; Paul Kristeller, "Woodcuts as Bindings." Bibliographica I (1895): 249-56.

7 Sophie Malavieille, Reliures et cartonnages d'éditeur au XIX siècle, 1815-1865. Paris: Promodis, 1985; Ruari McLean, Victorian Publishers' Bookbindings in Paper. London: Gordon Fraser, 1983.

${ }^{8}$ For example: Mirjam M. Foot, "An English Paper Binding c. 1698." Book Collector 30 (Spring 1981): 74-75; Howard M. Nixon, Catalogue of the Pepys Library at Magdalene College Cambridge. vol. 6. Bindings. Woodbridge, England: D. S. Brewer, 1984.

${ }^{9}$ F. J. Harvey Darton, Children's Books in England. 2nd ed. Cambridge: University Press, 1958; Jacques Paul Dauriac, "The Great Century of the Little Almanach: French Book Covers." Novum Gebrauchsgraphik 44 (August 1973): 44-51; Sydney Roscoe, John Newbery and His Successors, 1740-1814: A Bibliography. Wormley, England, Five Owls Press, 1973; Roy McKeen Wiles, Serial Publication in England Before 1750. Cambridge: University Press, 1957.

10 See Jackson; Adolf Rhein, "Die frühen Verlagseinbände eine technische Entwicklung, 1735-1850." Gutenberg Jahrbuch (1962): 519; and Paul Needham, Twelve Centuries of Bookbinding: 400-1600. New York: Pierpont Morgan Library, 117-19. 
where at least five were produced. ${ }^{11}$ Other paper woodcut wrappers of this period were produced at Ferrara slightly later; so far the earliest to come to light has been dated 1490.12

The sixteenth-century Italian and German book trade continued to use paper woodcut wrappers (which were also produced in France during this period ${ }^{13}$ ) until about mid-century. So far no woodcut wrappers have been dated between the middle and the end of the sixteenth century. However, so few

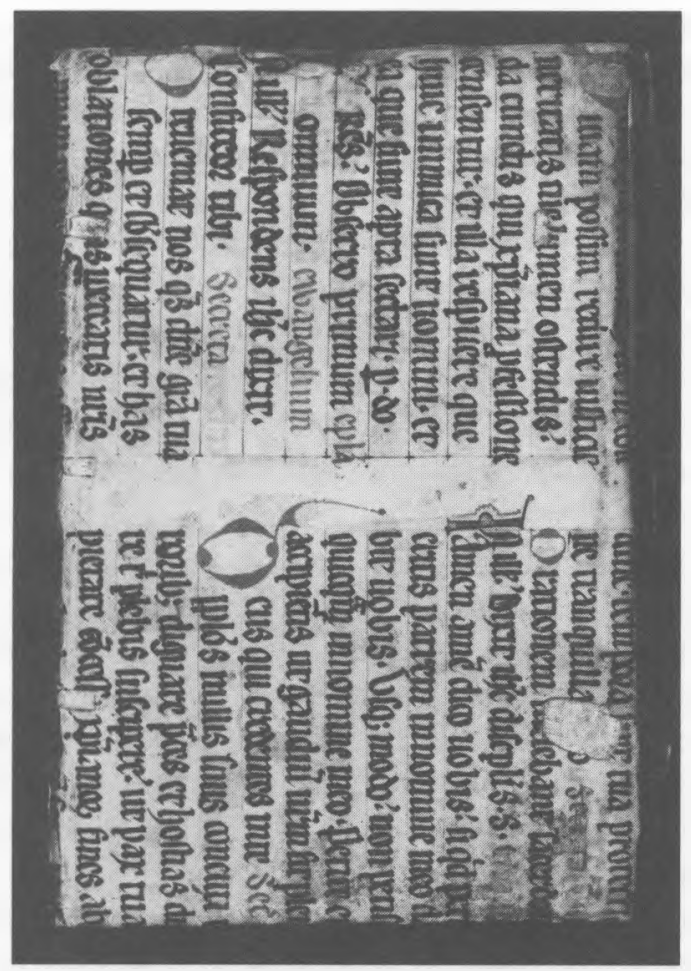

Book covered with vellum manuscript; paper manuscripts as well as early printed leaves were also used for covers.

11 Needham, 117-19.

12 Kristeller, 249-51; Needham, 155; Ernest Philip Goldschmidt, Gothic and Renaissance Bookbindings. 2 vols. London: E. Benn, 1928, vol. 1, 163.

${ }^{13}$ An example appears in Dorothy Miner, The History of Bookbinding, 525-1950 A.D. Baltimore: Walters Art Gallery, 1957, \#193d. Barber cites another example, 37. 
specimens from any period have survived that it is probably premature to draw any conclusions about their disappearance.

In 1579 the potential of paper as a binding material was promoted in another sector. In a treatise on papermaking, Samuel Zimmermann recommended that paper replace "Pirments [sic] oder Leders" for the binding of books..$^{14}$ Although there is no evidence that Zimmermann's work was influential, plain paper covers and wrappers were already being manufactured, though few have survived. Did the introduction of plain paper as a covering material coincide with any new practices in the European book trade? When did paper covers cease to be "the result of individual initiative" and become "regular trade practice"? ${ }^{15}$ It is not yet possible to establish when paper emerged as a recognized and acceptable substitute for certain types of leather and vellum bindings. More evident, however, is that once established the use of paper as a covering material never ceased. In fact, the Italian limp-paper covers-which were probably modeled on limp vellum prototypes - coexisted with them. It is possible that the paper and vellum bindings were produced in the same shops, perhaps even for the same books. Since the sewing structures were the same, a given edition could have consisted of vellum as well as paper covers.

From the seventeenth to the early nineteenth century, paper covers were produced in increasing quantities. Three primary structures were used: wrappers, cases (some of which were laced-in constructions), and boards. The simplest wrappers were those used on pamphlets: a single sheet of paper wrapped around the text block and then sewn through the fold with a figure-eight stitch or else stab stitched. More elaborate wrappers consisted of more than a single sheet of paper.

There were two types of cases: the limp-paper Italian structures mentioned above and rigid cases. The limp-paper structures were sewn on cords or thongs, which were laced through the covers. The covers were made from heavy paper rather than pasteboard; hence the term limp. They are also called lacedpaper cases, because the covers were made separately from the

${ }^{14}$ Samuel Zimmermann, Nezw Titularbuech . . . , Ingolstat, 1579, 123-24.

15 Barber, 37. 
book, ready for attachment. They vary somewhat from the rigid case structures, however, because they are not reinforced with boards, and they do not depend on the use of adhesives. After lacing, the covers were often covered with plain or decorated papers.

Many examples of paper case bindings can be found in 18th-century Germany, where they were commonly used on periodicals. These cases were often covered with decorated papers, and their structures were closer to nineteenth- and twentieth-century cases than were the limp-paper Italian covers. The German bindings were often given edge treatments and printed labels, and were, for the most part, publishers' bindings.

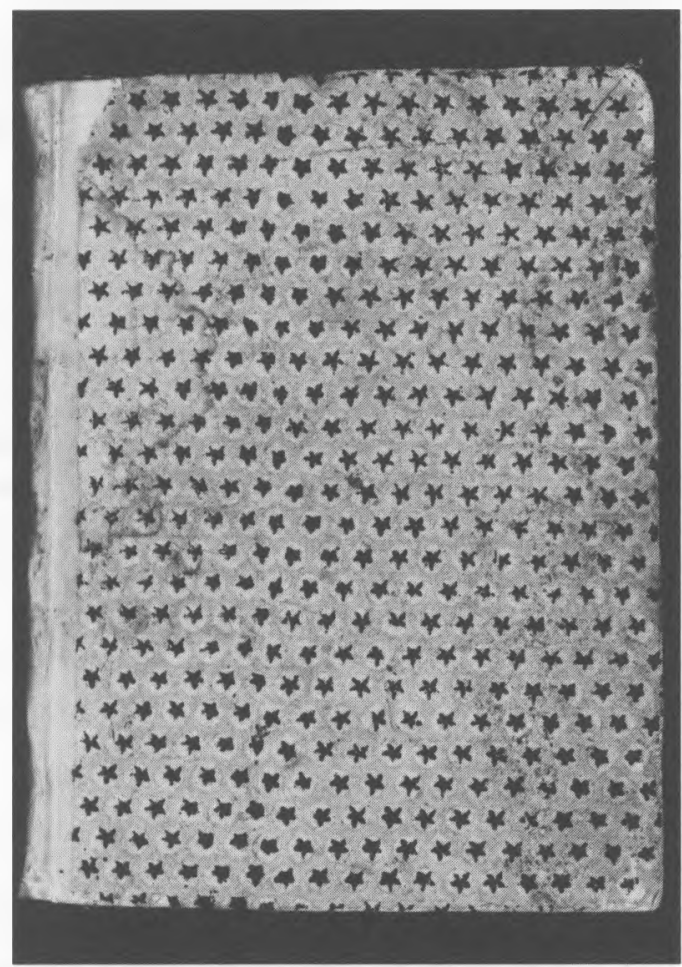

Block-printed paper over a vellum cover. 
The term boards generally refers to the binding of books in boards. It was used by John Carter ${ }^{16}$ and others to refer to books in paper-covered boards often distributed by publishers in the eighteenth and nineteenth centuries. A related term, board cover, is used by Glaister to denote books sewn on cords that were laced through the boards and then covered with three pieces of paper: one color for the spine, and another for the front and back covers. ${ }^{17}$

In the seventeenth century, Augsburg again became a center of activity, but through papers decorated with printed metallic varnish rather than plain woodcuts. Foot describes an example of this paper used on an English manuscript dated 169718 in the Pepys Library, where there are at least nine other similar examples.

By this time both plain and decorated papers were regularly used in England, France, Italy, Germany, and Holland. Why did the production of paper covers proliferate? How was the commerce in decorated papers throughout Europe related to the book trade? Such questions cannot yet be answered, although my own research in progress should eventually shed more light on these issues.

The eighteenth century is perhaps the richest period for the production of paper book covers, both in terms of the quantity of paper coverings produced and in the variety of their styles and structures. By mid-century, paper covers were in use throughout Europe and America, reflecting changes in the book trade and improved production binding techniques. The production of these in so many countries certainly accounts for the variety of styles. There were several types of limp-paper structures in Italy, paper-covered boards in England, and case bindings in Germany.

By the nineteenth century, paper book covers, particularly of the case structure, were coming to find a comfortable niche.

${ }^{16}$ John Carter, $A B C$ for Book Collectors. 6th ed., with corrections and additions by Nicolas Barker. London: Granada, 1982.

17 Geoffrey Ashall Glaister, Glaister's Glossary of the Book. 2nd ed., completely revised. Berkeley: University of California, 1979, 51.

${ }^{18}$ Foot, 74. Other examples in the Pepys Library are numbers 370, 1047, $1293,2019,2174,2184,2185,2490$, and 2588. 
Technical innovations and changes in the organization of the book trade, however, ultimately led to the decline of their use after the 1820s. Two major technical innovations that influenced bookbinding were the introduction of book cloth around 1825 and shortly thereafter the development of a stamping machine to facilitate high-quality printing on cloth. These led to the rapid proliferation of cloth bindings and to the further development of machine methods for their manufacture.

Changes in the organization of the book trade fostered the centralization and mechanization of bookbinding activities. Prior to the nineteenth century, printers and booksellers were also publishers, but by about 1800 a separate publishing industry was securely established. This led to the mass production of bookbindings. Although paper book covers contin-

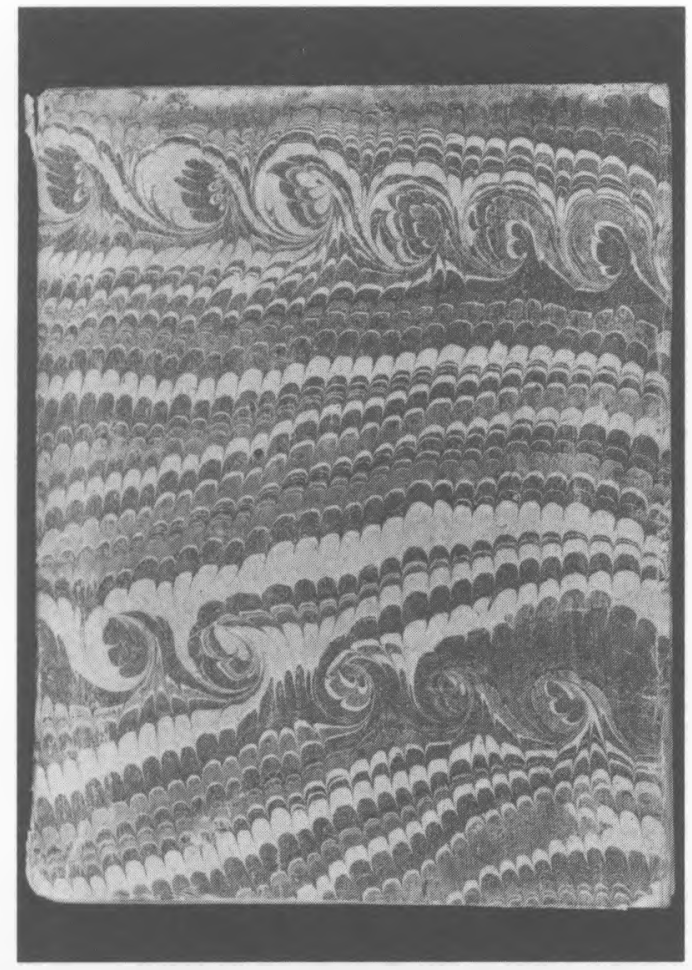

Dutch marbled wrappers, English seventeenthcentury. 
ued to be produced, they were manufactured by machine rather than by hand.

For the past 20 years, bookbinders, conservators, and papermakers have been examining pre-nineteenth-century papercovered book designs. A number of Italian laced-paper covers came to light after the November 1966 floods in Florence, Italy. Conservators have been particularly drawn to the nonadhesive designs since these have proved both durable and nondamaging to text blocks, while papermakers have been studying the cover paper used. ${ }^{19}$ It is ironic that paper book coverings-long dismissed as temporary structures-are now being examined for their durability.

${ }^{19}$ Betty Lou Chaika, "Visible Structure in Light Weight Binding." Ampersand 6 (Summer 1986): 4-6; Gary L. Frost. "Historical Paper Case Binding and Conservation Rebinding." New Bookbinder 2 (1982): 64-67; Michael Gullick, "Some Notes \& Reflections on Unsupported Sewing." Ampersand 6 (Summer 1986): 1-3; T [imothy] Barrett, "Paper Case Papers: Hands-on Session, Oxbow PBI 1986," Xeroxed handout. 